Ashar Ridovan', Andi Masnang ${ }^{2}$, Aisyah Henri ${ }^{3}$

${ }^{1,2}$ Program Studi Agroteknologi, Fakultas Pertanian, Universitas Nusa Bangsa, J1. K.H. Sholeh Iskandar Km. 4, Kelurahan Cibadak, Kecamatan Tanah Sareal, Bogor 16166, Indonesia, e-mail: ridov93@gmail.com e-mail korespondensi: andimasnang65@gmail.com

${ }^{3}$ Jurusan Agroteknologi, Universitas Gunadarma, J1. Margonda Raya No.100, Depok 16424, Indonesia, e-mail: aisyah_126@yahoo.co.id

\section{APLIKASI KOMPOS KULIT BUAH KAKAO PADA BIBIT KAKAO (Theobroma cacao L.)}

\author{
(Application of Cocoa Fruit Leather Compos on Cocoa \\ (Theobroma cacao L.) Seeds)
}

ISSN: 2721-8589 (media online) ISSN: 2721-8597 (media cetak)

\section{AGRISINTECH}

Journal of Agribusiness and Agrotechnology

Vol. 1 No. 1 April 2020

\begin{abstract}
The cocoa plant (Theobroma cacao L.) is one of the plantation plants that is expanded in the context of increasing the country's foreign exchange resources from the non-oil and gas sector. This study studies the effect of applying compost made from cocoa shells on the growth of cocoa seedlings (Theobroma cacao L.). The purpose of this study was to determine whether there was an effect of compost using cocoa as raw material, the parameters observed were plant height, number of leaves and diameter of cocoa seedlings, this study was conducted from January to June 2019 at the Spice and Refreshing Plant Research Institute (BALITTRI). Using the Complete Random Design Method(CRD). Consists of 5 treatments and 3 replications, with the treatment of compost $100 \mathrm{~g} /$ polybag, $200 \mathrm{~g} /$ polybag, $300 \mathrm{~g} /$ polybag, and $400 \mathrm{~g} /$ polybag. The data which is then obtained is then analysis of variance (ANOVA) and if significantly different, it is continued with the DMRT (Duncan's Multiple Range Test) test at 5\% level. The results showed that the treatment of organic fertilizer made from cocoa with a dose of $200 \mathrm{~g} /$ polybag gave optimal results but after further testing (DMRT) did not have a significant effect on plant height, stem diameter and number of leaves.
\end{abstract}

Keywords: cocoa, compost, seed

\begin{abstract}
ABSTRAK
Tanaman kakao (Theobroma cacao L.) merupakan salah satu tanaman perkebunan yang dikembangluaskan dalam rangka peningkatan sumber devisa negara dari sektor non-migas. Penelitian ini mempelajari tentang pengaruh pemberian pupuk kompos berbahan baku kulit kakao terhadap pertumbuhan bibit kakao (Theobroma cacao L.). Tujuan penelitian untuk mengetahui apakah ada pengaruh pemberian pupuk kompos berbahan baku kakao, parameter yang di amati adalah tinggi tanaman, jumlah daun dan diameter bibit tanaman kako, penelitian ini dilakukan dari bulan Januari - Juni 2019 di Balai Penelitian Tanaman Rempah dan Penyegar (BALITTRI). Dengan menggunakan Metode Rancangan Acak Lengkap (RAL). Terdiri dari 5 perlakuan dan 3 ulangan, dengan perlakuan pemberian kompos $100 \mathrm{~g} /$ polybag, $200 \mathrm{~g} /$ polybag, $300 \mathrm{~g} /$ polybag, dan $400 \mathrm{~g} /$ polybag. Data yang kemudian diperoleh selanjutnya dianalisa dengan sidik ragam (ANOVA) dan apabila berbeda nyata dilanjutkan dengan uji DMRT (Duncan's Mutiple Range Test) pada taraf 5\%. Hasil penelitian menunjukkan bahwa perlakuan pemberian pupuk organik berbahan baku kakao dengan dosis 200g/ polybag memberikan hasil yang optimal namun setelah dilakuakan uji lanjut (DMRT) tidak memberikan pengaruh nyata pada tinggi tanaman, diameter batang dan jumlah daun.
\end{abstract}

Kata kunci: kakao, kompos, bibit 


\section{PENDAHULUAN}

$\begin{array}{cccc}\text { Kakao } & \text { (Theobrema cacao L.) } \\ \text { merupakan } & \text { salah satu komoditas } \\ \text { perkebunan } & \text { yang peranannya cukup }\end{array}$ penting bagi perekonomian nasional, khususnya sebagai penyedia lapangan kerja, sumber pendapatan dan devisa negara. Luas tanaman menghasilkan kakao tahun 2017-2021 diperkirakan naik 3,00\% per tahun dimana pada tahun 2017 (estimasi Ditjen Perkebunan) sebesar 874,19 ha menjadi 969,36 ha tahun 2021 . Begitu juga produktivitas kakao diperkirakan naik $0,84 \%$ per tahun. Hasil perkalian luas tanaman yang menghasilkan dengan produktivitas kakao, maka hasilnya adalah produksi kakao tahun 2018-2021 diperkirakan naik 3,85\% per tahun. Tahun 2021 produksi kakao diperkirakan akan menjadi 793,47 ton (P. D. S. I. Pertanian, 2017). Produksi yang tinggi tersebut menghasilkan kulit buah kakao sebagai produk samping pertanian meningkat.

Kulit buah kakao merupakan salah satu limbah dari perkebunan kakao. Kulit buah kakao merupakan komponen terbesar dari buah kakao yaitu sebesar $70 \%$ berat buah masak. Menurut Hartobudoyo pada areal satu hektar pertanaman kakao akan menghasilkan produk samping segar kulit buah sekitar 5,8 ton (Hartobudoyo, 1995).

Produk samping kulit buah kakao yang dihasilkan dalam jumlah banyak akan menjadi masalah jika tidak ditangani dengan baik, apabila tidak dimanfaatkan dapat menimbulkan masalah lingkungan di sekitar perkebunan (Darmono \& Tri Panji, 1999). Salah satu cara untuk memanfaatkan kulit buah kakao adalah dijadikan kompos atau pupuk organik (Naibaho \& Ikhsan, 2017), artinya kebutuhan pupuk pada tanaman kakao dapat dipenuhi dari pemanfaatan limbah tanaman kakao, sehingga diharapkan mampu meningkatkan produksi dan memperbaiki kualitas kakao (Nappu, 2015). Pertumbuhan bibit kakao di lapangan sangat ditentukan oleh pertumbuhan tanaman selama di pembibitan. Media tanam merupakan salah satu faktor yang tanaman kakao di pembibitan. Pengguna an media tanam dari kompos kulit kakao yang banyak mengandung bahan organik (Damanik, Henni Fiona, \& Jonis Ginting, 2013) sangat menguntungkan bagi pertumbuhan tanaman kakao. Pengomposan limbah kulit kakao yang menghasilkan bahan organik dapat meningkatkan kualitas sifat fisik tanah seperti struktur tanah yang lebih remah dan mempercepat penyerapan unsur hara (Yelianti, Kasim, \& Husin, 2009). Selanjutnya hasil penelitian Shalsabila menunjukkan bahwa limbah kakao yang dijadikan biochar dan meningkatkan stabilitas agregat pada tanah Ultisol (Shalsabila, Prijono, \& Kusuma, 2017).

Kandungan hara kompos dari kulit buah kakao adalah $1,81 \% \mathrm{~N}, 26,61 \% \mathrm{C}$-organik, $0,31 \% \quad \mathrm{P} 2 \mathrm{O} 5,6,8 \% \mathrm{~K} 2 \mathrm{O}, 1,22 \% \mathrm{CaO}$, $1,37 \% \mathrm{MgO}$ dan $44,85 \mathrm{cmol} / \mathrm{kg}$ KTK (Didiek H.G., 2004).

Berdasarkan potensi dari kulit buah kakao, maka perlu dilakukan pemanfaatan kulit buah kakao sebagai upaya penanggulangan limbah buah kakao, salah satunya adalah menjadi bahan campuran kompos. Berdasarkan potensi tersebut, peneliti merasa perlu melakukan penelitian ini dengan tujuan mengetahui respon pertumbuhan bibit tanaman kakao dari aplikasi kompos kulit kakao (Theobroma cacao L.)

\section{METODE PENELITIAN}

Penelitian dilakukan selama bulan April - Juni 2019 di rumah kaca Balai Penelitian Tanaman Industri dan Penyegar (BALITTRI), yang berlokasi di Jalan Raya Pakuwon Km.2 Kelurahan Sundawenang Kecamatan Parungkuda, Kabupaten Sukabumi.

Alat yang digunakan dalam penelitian adalah ember besar untuk wadah membuat 
kompos kulit buah kakao, cangkul untuk mengambil media tanah, golok untuk menyacah kulit buah kakao, penggaris, sigmat untuk mengukur bibit tanaman, kamera untuk mendokumentasikan dan penunjang penelitian dan alat tulis lainnya.

Bahan yang digunakan dalam penelitian ini adalah sebagai berikut: Bibit kakao sebagai objek penelitian, kulit buah kakao sebagai bahan kompos, pupuk kandang sebagai tambahan pupuk dasar, sekam bakar untuk tambahan pupuk kompos, Em4 bakteri pengurai untuk pembuatan kompos, gula pasir untuk campuran pembuatan pupuk kompos dan air bersih non kaporit sebagai tambahan pembuatan kompos.

Pembuatan kompos kulit buah kakao menggunakan bahan sesuai dengan kebutuhan kompos yang di buat terdiri dari kulit buah kakao yang sudah di cincang sebanyak $60 \mathrm{~kg}$, pupuk kandang $45 \mathrm{~kg}$, top soil $45 \mathrm{~kg}$ sekam bakar $3 \mathrm{~kg}$, gula pasir $1 / 2$ $\mathrm{kg}$, dekomposer Em4 $225 \mathrm{~mL}$ dan air secukupnya.

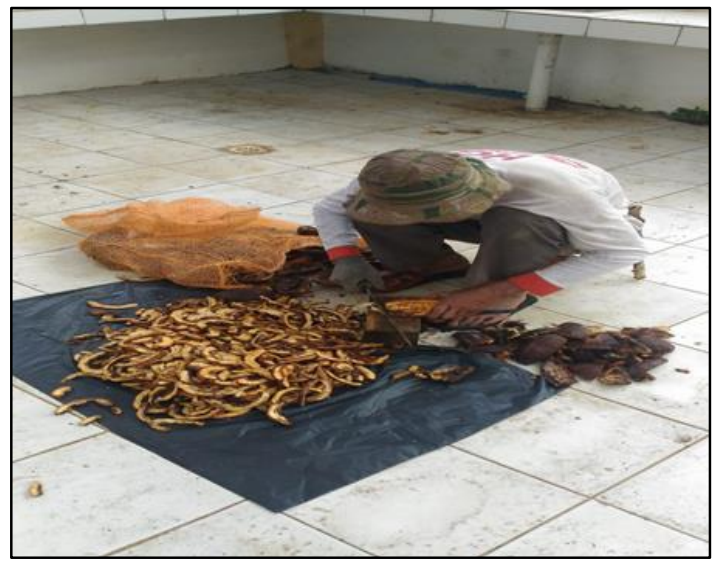

Sumber: Data primer (2019)

Gambar 1. Cacahan kulit kakao

Semua bahan dicampur dan diaduk sampai rata didalam ember besar, kemudian disiram larutan dekomposer EM4 secara perlahan kedalam adonan. Adonan ditutup rapat dan dibuka untuk membuang udara di dalam ember selama 10 hari sekali selama satu bulan.

\section{Teknik Pengumpulan Data}

Penelitian dilaksanakan secara eksperimental dengan menggunakan rancangan acak lengkap (RAL) terdiri dari lima perlakuan per polybag:

B0 $=0 \quad$ g pupuk kompos/Polybag

$\mathrm{B} 1=100 \mathrm{~g}$ pupuk kompos/Polybag

$\mathrm{B} 2=200 \mathrm{~g}$ pupuk kompos/Polybag

B3 $=300$ g pupuk kompos/Polybag

B4 = 400 g pupuk kompos/Polybag

Pemberian kompos per polybag diulang tiga kali, sehingga diperoleh 15 unit percobaan. Tiap percobaan terdiri dari dua tanaman dan sekaligus dijadikan sampel sehingga terdapat 30 tanaman.

\section{Parameter Pengamatan}

a. Tinggi Tanaman

Tinggi tanaman diukur mulai dari $2 \mathrm{~cm}$ dari permukaan tanah sampai titik tumbuh, diukur pada saat tanaman berumur 4 minggu pengamatan dimulai minggu ke-4, ke-7 dan ke-9 dengan interval pengukuran 3 minggu sekali

b. Jumlah daun

Jumlah daun dihitung sejak tanaman berumur 4 minggu setelah dipindahkan ke dalam polybag sampai berumur 9 minggu dengan interval pengukuran 3 minggu sekali.

\section{c. Diameter Batang}

Diameter batang diukur dengan menggunakan jangka sorong setelah bibit berumur 4 minggu setelah dipindahkan ke dalam polybag dengan interval pengukuran 3 minggu sekali hingga berumur 9 minggu, yang dilakukan pada ketinggian $2 \mathrm{~cm}$ dari permukaan tanah dalam polybag.

\section{Analisa Data}

Data yang diproleh dianalisa secara statistik menggunakan Analisa dengan model linier dalam perangkat lunak SPSS Versi 22. 


\section{HASIL DAN PEMBAHASAN}

\section{Tinggi Tanaman}

Berdasarkan hasil rata-rata pengamatan tinggi tanaman setelah dilakukan analisa sidik ragam menunjukkan bahwa pemberian pupuk kompos kulit buah kakao berpengaruh tidak nyata terhadap tinggi bibit tanaman kakao. Hasil analisa raga (anova) pada taraf 5\% terhadap rata-rata tinggi tanaman kakao dapat dilihat pada Gambar 2.

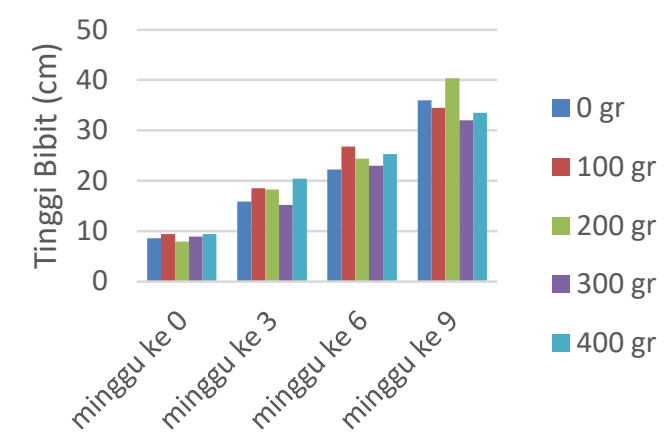

Sumber: Olahan data primer, (2019)

Gambar 2. Rata-rata tinggi tanaman bibit tanaman kakao

Gambar 2 menunjukkan bahwa pemberian kompos kulit buah kakao dosis $200 \mathrm{~g} /$ polybag menghasilkan tinggi tanaman yang lebih mendominasi diantara pemberian dosis kompos yang lainnya. Hasil pengamatan diperoleh tinggi tanaman pada dosis $200 \mathrm{~g} /$ polybag yaitu $18,3 \mathrm{~cm}$ pada minggu ketiga, $24,4 \mathrm{~cm}$ di minggu keenam, dan 40,4 cm di minggu kesembilan. Standar tinggi tanaman kakao yang dikeluarkan oleh Direktorat Jendral Perkebunan Departemen Pertanian, pada bibit tanaman kakao umur 3-6 bulan yaitu $20 \mathrm{~cm}$, artinya pertambahan tinggi bibit tanaman kakao dengan pemberian kompos kulit buah kakao yang dikomposkan memenuhi standar. Hal ini karena kandungan unsur hara yang terdapat pada kompos kulit buah kakao dengan dosis 200 $\mathrm{g} /$ tanaman telah mencukupi untuk pertumbuhan tinggi tanaman kakao (D. J. P. K. Pertanian, 2013).
Peningkatan tinggi tanaman sangat dipengaruhi oleh unsur hara yang dibutuhkan tanaman, lingkungan yang menguntungkan dan baiknya serapan hara oleh tanaman sehingga membentuk pertumbuhan dan perkembangan tanaman menjadi optimal melalui pemberian perlakuan. Gambar 2 menunjukkan tinggi tanaman lebih baik akibat pemberian perlakuan kompos dibandingkan tanpa pemberian perlakuan kompos pada setiap pengamatan.

Pertambahan tinggi tanaman sangat erat kaitannya dengan unsur hara makro seperti nitrogen, fosfor dan kalium. Unsur hara nitrogen merupakan komponen penyusun asam amino, protein dan pembentukan protoplasma sel yang dapat berfungsi dalam merangsang pertumbuhan tinggi tanam (Lingga, 2001). Fosfor berperan terhadap pembelahan sel pada titik tumbuh yang berpengaruh pada tinggi tanaman. Unsur kalium juga berperan meningkatkan pertumbuhan tanaman yang berperan sebagai aktivator berbagai enzim (Harjadi, 2002).

Kompos kulit buah kakao mengandung hara mineral cukup tinggi, khususnya hara Kalium dan Nitrogen, unsur $\mathrm{K}$ berperan dalam mempercepat pertumbuhan meristematik. Sedangkan N berperan untuk mempercepat pertumbuhan vegetatif tanaman seperti tinggi tanaman, besar batang, dan pembentukan daun (Lingga, 2001). Pemberian kompos kulit buah kakao mampu memperbaiki sifat fisik, kimia, dan biologi tanah. Damanik, et al., (2013) menyatakan bahwa bahan organik akan meningkatkan aktifitas biologi tanah dan kegiatan jasad mikro dalam membantu proses dekomposisi. Bahan organik yang terkandung di dalam kompos kulit buah kakao dapat meningkatkan daya ikat air, serta memperbaiki aerase dan drainase tanah (Damanik, Henni Fiona, \& Jonis Ginting, 2013). 
Bahan organik akan memperbaiki struktur tanah sehingga ketersedian unsur hara yang akan diserap tanaman semakin meningkat pula. Peningkatan penyerapan unsur hara akan meningkatkan pertumbuhan dan produksi tanaman, dengan demikian hal ini sangat mendukung pertumbuhan yang lebih baik dari pembibitan (Hardjowigeno, 2004).

\section{Diameter Batang}

Berdasarkan hasil rata-rata pengamatan diameter batang tanaman setelah dilakukan analisa ragam bahwa pemberian pupuk kompos kulit buah kakao berpengaruh tidak nyata terhadap diameter bibit tanamn kakao. Pertumbuahan bibit tanaman kakao (Gambar 3) dimana pemberian 200 gr dosis pupuk kompos kulit buah kakao terhadap diameter batang tanaman kakao lebih mendominasi dibandingkan pemberian dosis pupuk kompos lainnya.

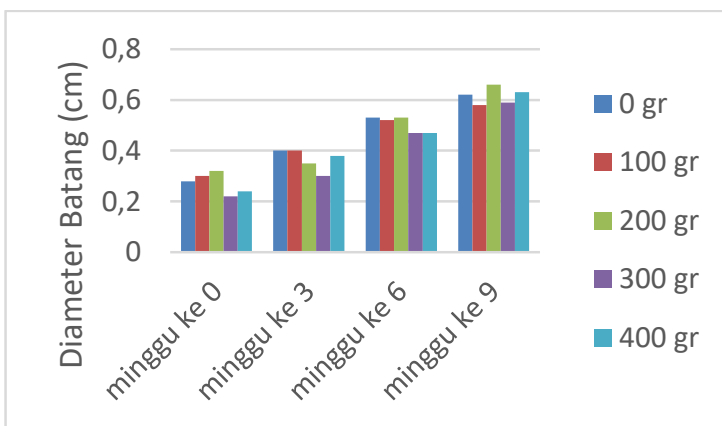

Sumber: Olahan data primer (2019)

Gambar 3. Rata-rata diameter batang tanaman bibit tanaman kakao.

Berdasarkan Gambar 3, pemberian kompos kulit buah kakao dosis 200 g/tanaman menghasilkan lingkar batang yang paling efektif yaitu $0,66 \mathrm{~cm}$ pada pengamatan diminggu ke-9. Hal ini menunjukkan bahwa lingkar batang tanaman kakao dengan pemberian kompos kulit buah kakao sudah memenuhi standar. Terjadinya pertambahan lingkar batang karena kandungan unsur hara yang terdapat pada kompos kulit buah kakao cenderung mencukupi untuk pertumbuhan lingkar batang tanaman kakao. Tersedianya unsur hara dalam jumlah yang cukup menyebabkan kegiatan metabolisme dari tanaman akan meningkat demikian juga akumulasi asimilat pada daerah batang akan meningkat sehingga terjadi pembesaran pada bagian batang.

Pertumbuhan batang tidak hanya pertambahan tinggi namun pembesaran diameter batang juga terjadi karena tanaman menjalankan fungsi fisiologisnya. Pemberian kulit buah kakao pada parameter lingkar batang tanaman kakao dapat meningkatkan lingkar batang karena selama pertumbuhannya tanaman mendapatkan unsur hara selain dari tanah juga mendapatkan sumbangan hara dari kompos tersebut. Pemberian kompos dapat mengaktifkan jasad renik dan dapat mempertinggi daya serap tanah terhadap unsur yang tersedia, sehingga dapat meningkatkan kesuburan tanah dan kegemburan tanah (Lingga, 2001). Kompos kulit buah kakao mengandung unsur hara $\mathrm{K}$ yang cukup tinggi yaitu $1,23 \%$. Hal ini didukung oleh Leiwakabessy (1988) yang menyatakan bahwa unsur $\mathrm{P}$ dan $\mathrm{K}$ sangat berperan dalam meningkatkan diameter batang tanaman, khususnya dalam peranannya sebagai jaringan yang menghubungkan antara akar dan daun. Tersedianya unsur hara $\mathrm{P}$ dan $\mathrm{K}$ mengakibatkan pembentukan karbohidrat akan berjalan dengan baik dan translokasi pati ke batang akan semakin lancar, sehingga akan terbentuk batang yang baik. Fosfor dan Kalium berperan dalam membantu pembentukan organ tanaman (Leiwakabessy, 1988).

\section{Jumlah Daun}

Berdasarkan hasil rata-rata pengamatan penghitungan jumlah daun tanaman kakao setelah dilakukan analisa sidik ragam bahwa interaksi pemberian pupuk kompos kulit buah kakao berpengaruh tidak nyata terhadap jumlah daun bibit tanaman kakao. Pertumbuhan bibit tanaman kakao dimana pemberian 100 gr dosis pupuk kompos kulit buah kakao lebih mendominasi terhadap jumlah daun tanaman kakao dibandingkan 
pemberian dosis pupuk kompos lainnya (Gambar 4).

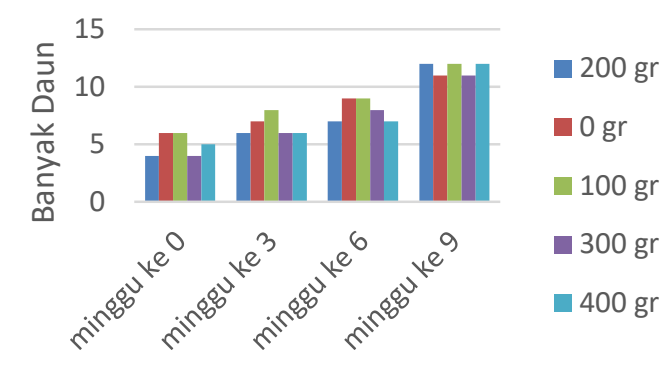

Sumber: Olahan data primer (2019)

Gambar 4. Rata-rata jumlah daun tanaman bibit tanaman kakao

Gambar 4 menunjukkan bahwa pemberian kompos kulit buah kakao terhadap pertumbuhan bibit kakao berbeda tidak nyata pada parameter jumlah daun. Perlakuan pemberian kompos kulit buah kakao $100 \mathrm{gr} /$ tanaman memberikan hasil yang paling efektif terhadap parameter jumlah daun yaitu 12 helai dilihat dari hasil pengamatan minggu ke- 9. Hal ini dikarenakan jumlah daun lebih didominasi oleh pengaruh faktor genetik. Standar jumlah daun bibit tanaman kakao yang dikeluarkan oleh Direktorat Jendral Perkebunan Departemen Pertanian (2013) pada bibit tanaman kakao umur 3-6 bulan yaitu 10 helai, artinya jumlah daun bibit tanaman kakao dengan pemberian kompos kulit buah kakao sudah memenuhi standar. Hal ini karena kandungan unsur hara yang terdapat pada kompos kulit buah kakao cenderung mencukupi untuk pertumbuhan jumlah daun bibit tanaman kakao. Semakin banyak jumlah daun yang dihasilkan maka klorofil semakin tersedia dan fotosintesis semakin besar. Fungsi daun sebagai organ fotosintesis akan berjalan dengan baik sehingga fotosintat yang dihasilkan cukup dan dapat menyebabkan terbentuknya daun-daun baru pada tanaman.

Lingga dan Marsono (2001) menyatakan bahwa nitrogen dalam jumlah yang cukup berperan dalam mempercepat pertumbuhan tanaman secara keseluruhan, khususnya batang dan daun. Kandungan nitrogen yang terdapat dalam tanah akan dimanfaatkan oleh tanaman kakao dalam pembelahan sel. Pembelahan dan pembesaran sel akan memicu terbentuknya daun tanaman kakao. Daun merupakan organ tanaman yang menentukan kelangsungan hidup tanaman, karena dalam daun terjadi proses fotosintesis, respirasi dan transpirasi.

Daun dan ukuran daun pada tanaman pada dasarnya dipengaruhi oleh faktor genetik dan lingkungan tumbuh tanaman tersebut (Lakitan, 1996). Proses pertumbuhan dan perkembangan daun dipengaruhi oleh faktor genetik dari tanaman itu sendiri sehingga dapat mempengaruhi jumlah daun, selain itu ketersediaan unsur hara juga dapat mempengaruhi jumlah daun (Gardner, 1991). Lakitan (1996) menambahkan bahwa unsur hara yang paling berpengaruh terhadap pertumbuhan dan perkembangan daun adalah nitrogen yang berperan dalam sintesis klorofil, protein, pembentukan selsel baru, sehingga mampu membentuk organ-organ seperti daun.

\section{SIMPULAN}

Pemberian pupuk kompos berbahan baku kulit kakao memberikan pengaruh tidak nyata terhadap tinggi, diameter batang dan jumlah daun. Namun demikian, perlakuan terbaik dari hasil pengamatan yaitu pemberian kompos kulit buah kakao dengan dosis $200 \mathrm{~g} /$ polybag.

\section{DAFTAR PUSTAKA}

Damanik, Henni Fiona, \& Jonis Ginting, I. (2013). Respons Pertumbuhan Bibit Kakao (Theobroma cacao L.) Terhadap Beberapa Komposisi Kompos Kulit Buah Kakao Dengan Subsoil Ultisol Dan Pupuk Daun. Jurnal Online Agroekoteknologi, 2(1), 162-171. Retrieved from https://jurnal.usu.ac.id/index.php/agro ekoteknologi/article/download/5749/ 2511 
Darmono \& Tri Panji. (1999). Penyediaan Kompos Kulit Buah Kakao Bebas Phytophthora palmivora. Warta Penelitian Perkebunan, 5(1), 33-38.

Didiek H.G., \& Y. A. (2004). Orgadek, Aktivator Pengomposan. Pengembangan Hasil Penelitian Unit Penelitian Bioteknologi Perkebunan Bogor.

Gardner, F. P. R. . P. \& F. L. M. (1991). Fisiologi Tanaman Budidaya. Jakarta: Terjemahan Universitas Indonesia Press.

Hardjowigeno, S. (2004). Genesis dan Klasifikasi Tanah. Bogor: Institut Pertanian Bogor.

Harjadi, M. M. S. S. (2002). Pengantar Agronomi. Jakarta: Gramedia.

Hartobudoyo. (1995). Bertanam Cacao. Yogyakarta: Kansius.

Lakitan, B. (1996). Dasar-Dasar Fisiologi Pertumbuhan dan Perkembangan Tanaman. Jakarta: PT. Raja Grafindo Persada.

Leiwakabessy, F. M. (1988). Diktat Kuliah Kesuburan Tanah. Bogor: Departemen Tanah, Fakultas Pertanian IPB.

Lingga, P. dan M. (2001). Petunjuk Penggunaan Pupuk. Jakarta: Penebar Swadaya.

Naibaho, J., \& Ikhsan, A. (2017). Pemberian Kompos Kulit Buah Kakao Pada Medium Ultisol Untuk Pertumbuhan Bibit Kakao
(Theobroma cacao L ) The effect of cocoa fruit skin compost on the ultisol medium for the growth of cocoa seedling ( Theobroma cacaol L ). JOM FAPERTA, 4(2), 1-11.

Nappu, M. . (2015). Model Pertanian Bioindustri Pada Sentra Pengembangan Kakao Di Sulawesi Selatan (p. 57). p. 57. Makassar: Balai Pengkajian Teknologi Pertanian Sulawesi Selatan.

Pertanian, D. J. P. K. (2013). Kebijakan Peningkatan Produksi dan Mutu Kakao dalam Mendukung Hilirisasi dan Peningkatan Pendapatan Petani (p. 26). p. 26. Retrieved from https://docplayer.info/storage/52/301 66784/1578974234/cQYQa5DDfqN Q7QqH5uEUGA/30166784.pdf

Pertanian, P. D. S. I. (2017). Outlook 2017 Komoditas Pertanian Sub Sektor Perkebunan: Kakao. Retrieved from http://epublikasi.setjen.pertanian.go.i d/download/file/403-outlook-kakao2017\%0A

Shalsabila, F., Prijono, S., \& Kusuma, Z. (2017). Pengaruh aplikasi biochar kulit kakao terhadap kemantapan agregat dan produksi tanaman jagung pada ultisol lampung timur. Jurnal Tanah Dan Sumberdaya Lahan, 4(1), 473-480.

Yelianti, U., Kasim, M., \& Husin, E. . (2009). Kualitas Pupuk Organik Hasil Dekomposisi Beberapa Bahan Organik dengan Dekomposernya. Akta Agrosia, 12(1), 1-7. Retrieved from http://faperta.unib.ac.id 